\title{
Rancangan Grafik Ukuran Antropometri, Ketebalan Lemak Dan Kecukupun Gizi Berdasarkan Metode Regresi Spline Sebagai Prediktor Kondisi Stunting Pada Balita
}

\author{
Diane Marlin $^{1 *}$, Rini Mustika Sarikurnia Pratama ${ }^{2}$ \\ ${ }^{1}$ Universitas Adiwangsa Jambi \\ ${ }^{2}$ Stikes Keluarga Bunda \\ *Correspondence email: dy.dian90@gmail.com
}

\begin{abstract}
Abstrak. Periode usia 24-59 bulan sistem sensorik balita telah siap menghadapi berbagai stimulasi dan tumbuh kembang, seperti belajar berbicara lebih lancar dan mengenali kondisi lingkungan, petumbuhan fisik, psikologis. Tidak semua balita dapat tumbuh secara optimal. Salah satu bentuk kegagalan tumbuh kembang pada masa balita adalah stunting. Indonesia merupakan negara dengan kondisi stunting tertinggi ke lima di dunia dalam satu dekade terakhir. Sekitar 37\% (hampir 9 Juta) anak balita di Indonesia mengalami stunting. Stunting tentunya dapat dihindari dengan mengetahui penyebab dan tanda kemungkinan seperti : 1) Ukuran antropometri di bawah standar, 2) Kecukupan nutrisi yang rendah, 3) Indeks Masa Tubuh Orang Tua, 4) Usia risiko tinggi pada saat hamil, 5) Sanitasi lingkungan yang tidak terjaga dengan baik. Indikator ukuran antropometri seperti Tinggi Badan, Berat Badan dan Lingkar kepala digunakan sebagai kriteria utama untuk menilai kecukupan asupan gizi dan pertumbuhan fisik bayi dan balita. Di Indonesia kurva pertumbuhan balita yang biasa digunakan yaitu Kartu Menuju Sehat (KMS). Kurva KMS ini dirancang berdasarkan rujukan World Health Organization (WHO) dan Nations International Children's Emergency Fund (NCHS). Berdasarkan ketidaksesuaian tersebut maka penelitian ini bertujuan untuk merancang grafik standar pertumbuhan fisik balita berdasarkan antropometri (Tinggi Badan, Berat Badan, Lingkar Kepala, Lingkar Dada, Lingkar betis), ketebalan lemak dan kecukupan gizi balita sesuai dengan ukuran fisik rata - rata balita di Indonesia, selain itu juga menilai kecukupan gizi di daerah yang memiliki faktor penghambat asupan gizi. Grafik standar pertumbuhan ini dirancang menggunakan metode regresi spline. Penelitian ini menggunakan rancangan cross sectional dimana pengukuran dilakukan satu kali. Sampel dalam penelitian adalah balita yang berada di tempat penelitian yang memenuhi kriteria inklusi. Berdasarkan hasil Analisa data data dan perancangan mode kurva didapatkan mode spline kubik orde tiga dengan kombinasi dua titik knot yaitu knot 9 dan 21 serta nilai GCV minimum sebesar 2,1267. Nilai asumsi linear terpenuhi dengan nilai $R^{2}=82,54$. yaitu linearitas, normalitas dan residu nol konstan terpenuhi.
\end{abstract}

Kata kunci : Antropometri; Kecukupan gizi; Balita; Stunting

Abstract. In the period of 24-59 months of age, the sensory system of toddlers is ready to face various stimulations and growths, such as learning to speak more fluently and recognizing environmental conditions, physical and psychological growth. Not all toddlers can grow optimally. One form of growth failure during toddlerhood is stunting. Indonesia is the country with the fifthhighest stunting condition in the world in the last decade. Around 37\% (nearly 9 million) of children under five in Indonesia are stunted. Stunting can of course be avoided by knowing the possible causes and signs such as 1) Under-standard anthropometric measures, 2) Low nutritional adequacy, 3) Body Mass Index for Parents, 4) Age at high risk during pregnancy, 5) Poor environmental sanitation. well preserved. Anthropometric measurement indicators such as height, weight, and head circumference are used as the main criteria for assessing the adequacy of nutritional intake and physical growth of infants and toddlers. In Indonesia, the growth curve for children under five that is commonly used is KartuMenujuSehat (KMS). The KMS curve is designed based on references from the World Health Organization (WHO) and the Nations International Children's Emergency Fund (NCHS). Based on this mismatch, this study aims to design a graph of physical growth standards for toddlers based on anthropometry (height, weight, head circumference, chest circumference, calf circumference), fat thickness, and nutritional adequacy of toddlers according to the average physical size of toddlers in Indonesia. Also, it assesses the adequacy of nutrition in areas that have inhibiting factors for nutrient intake. This growth standard graph is designed using the spline regression method. This study used a cross-sectional design where measurements were carried out once. The sample in this study were children under five who were in the study who met the inclusion criteria. Based on the results of data analysis and the design of the curve mode, the third-order cubic spline mode is obtained with a combination of two knots, namely 9 and 21 knots, and a minimum GCV value of 2.1267. The linear assumption value is fulfilled with a value of $R 2=82.54$. i.e. linearity, normality, and a constant zero residue are met.

Keyword: Anthropometr; Nutritional Adequacy; Toddler Stunting

\section{PENDAHULUAN}

Masa balita merupakan periode dimana pertumbuhan fisik dan psikis berkembang dengan pesat. Periode ini otak balita telah siap menghadapi berbagai stimulasi seperti belajar berbicara lebih lancar dan mengenali kondisi lingkungan. Anak yang bergizi baik menjadi aset bagi Sumber Daya Manusia (SDM) bangsa kedepan. Masalah gizi seperti wasting, Kekurangan 
Energi Kronik (KEK), dan stunting menjadi masalah nasional di Indonesia. Kelompok usia yang rentan terhadap masalah gizi tersebut salah satunya pada usia balita yaitu usia 2 sampai dengan 5 tahun. Salah satu bentuk kegagalan tumbuh kembang yang optimal pada masa balita adalah stunting (Torlesse et al, 2016).

Stunting berdampak terhadap peningkatan risiko morbiditas anak, mempengaruhi perkembangan kognitif, motorik kasar dan motorik halus, meningkatkan KEK dan wasting, menurunkan kemampuan belajar dan kemampuan sosial yang buruk (IDAI, 2011; Achadi LA, 2012). Tingkat kognitif rendah dan gangguan pertumbuhan pada balita stunting merupakan faktorfaktor yang dapat menyebabkan kehilangan produktivitas dan kiner kerja rendah pada saat dewasa (Black RE et al, 2013).

Indonesia merupakan negara dengan kondisi stunting tertinggi kelima di dunia dalam satu dekade terakhir. Sekitar 37\% (hampir 9 Juta) anak balita di Indonesia mengalami stunting Jika tren ini terus berlanjut Indonesia tidak mungkin mencapai tujuan World Health Assembly 2012 untuk mengurangi stunting sebesar $40 \%$ pada tahun 2025 (International Food Policy Research Institute, 2014; Kementerian Kesehatan RI, 2013).

Indonesia sebagai negara lintas benua memiliki keragaman etnis yang besar, demografi wilayah dan kultur budaya yang beragam. Lebih dari 300.000 dari 34 provinsi di Indonesia data individual telah dianalisis mengenai tinggi dan berat badan anak maupun remaja. Berdasarkan data yang dinalisis terdapat ketidaksesuaian antara batas ukuran pada tinggi dan berat badan anak dan remaja diindonesia dengan referensi standar World Health Organization (WHO). Anak-anak dan remaja Indonesia berjenis kelamin laki - laki atau perempuan secara signifikan memiliki ukuran tinggi badan lebih rendah dari standar WHO. Sementara berat badan sedikit lebih tinggi dari standar WHO. Kecuali pada bayi baru lahir yang tidak terlihat perbedaan signifikan (Aman, et al 2018).

Dalam penelitian lain kurva pertumbuhan standar yang dikeluarkan oleh WHO menggambarkan pertumbuhan anak umur 0-59 bulan, dimana kurva tersebut menggambarkan pertumbuhan anak yang hidup di lingkungan yang minim faktor penghambat pertumbuhan dan diteliti pada anak-anak di negara Brasil, Guatemala, India, Filipina dan Afrika Selatan (WHO, 2014; Dian et al,2011)

Penelitian terdahulu oleh Gorter FJ and $\mathrm{JH}$ de Haas, (1947) ; Liem Tjay Tie S and de Haas JH, (1938) dan Dhong TE., et al, (1939) dalam penelitian Aman (2018) menyatakan bahwa pertumbuhan anak Indonesia telah didokumentasikan sejak dulu setengah dari abad ke-20. Ukuran antropometri anak-anak Indonesia lebih pendek dari pada anak-anak Eropa modern dan lebih rendah dari yang disarankan oleh standar pengukuran fisik internasional. Sehingga ketika membandingkan tinggi anak-anak Indonesia dengan berbagai standar Internasional seperti Standar Pertumbuhan WHO, grafik pertumbuhan Centers for Disease Control and Prevention (CDC), kurva pertumbuhan Nations International Children's Emergency Fund (NCHS) atau grafik pertumbuhan United Kingdom-WHO maka sebagian besar ukuran antropometri anak-anak di Indonesia berada di bawah batas standar dan dianggap kerdil (Aman, et al 2018; Dian et al, 2011).

Indikator ukuran antropometri digunakan sebagai kriteria utama untuk menilai kecukupan asupan gizi dan pertumbuhan bayi dan balita. Pengukuran antropometri merupakan data referensi untuk mengevaluasi dan mencatat pertumbuhan anak. Hal ini di mulai dengan perbandingan umur dan jenis kelamin dalam pertumbuhan fisik balita. Pengukuran antropometri yang digunakan sebagai kriteria dalam penilaian pertumbuhan fisik adalah tinggi badan, berat badan, lingkar kepala, lipatan kulit, lingkar lengan atas, panjang lengan, lingkar kepala dan panjang tungkai ( IDAI, 2011; Zilda et al 2013)

Stunting didefinisikan sebagai tinggi badan yang lebih dari dua standar deviasi di bawah standar World Health Organization (WHO). (WHO, 2014). Balita pendek (stunted) dan sangat pendek (severely stunted) adalah balita dengan panjang badan $(\mathrm{PB} / \mathrm{U})$ atau tinggi badan (TB/U) menurut umurnya dibandingkan dengan standar baku WHO-MGRS (Multicentre Growth Reference Study) 2006. Sedangkan definisi stunting menurut Kementerian Kesehatan (Kemenkes) adalah anak balita dengan nilai z-scorenya kurang dari 2SD/standar deviasi (stunted) dan kurang dari - 3SD (severely stunted) (IDAI, 2011).

Indikator ukuran antropometri digunakan sebagai kriteria utama untuk menilai kecukupan asupan gizi dan pertumbuhan bayi dan balita. Pengukuran antropometri pada dasarnya ada dua macam, yakni antropometri statis yang dilakukan dalam keadaan diam, dan antropometri dinamis yang dilakukan dalam keadaan bergerak. Untuk kepentingan klinis, yang digunakan adalah antropometri statis (FK UNS, 2018)

Instrumen yang digunakan dalam pengukuran antropometri ada berbagai macam yang masing-masing memiliki kepekaan dan prosedur penggunaan yang berbeda (FK UNS, 2018) (Pengukuran antropometri (berat badan, tinggi badan dan lingkar lengan) sebenarnya sangat mudah dilakukan namun juga sekaligus rawan terhadap bias. Untuk menghindari bias dan error data maka hal yang perlu diperhatikan adalah kualitas alat yang digunakan dan ketelitian pewawancara dalam mengukur kecukupan gizi, pengukuran ini menggunakan metode kuesioner Food Frequency yang akan disi oleh orang tua Balita. kuesioner Food Frequency untuk memperoleh data tentang frekuensi konsumsi makanan jadi selama periode tertentu seperti hari, minggu, bulan atau tahun, Kuesioner Food Frequency memuat tentang daftar makanan yang ada 
Diane Marlin dan Rini Mustika Sarikurnia Pratama, Rancangan Grafik Ukuran Antropometri, Ketebalan Lemak Dan Kecukupun Gizi Berdasarkan Metode Regresi Spline Sebagai Prediktor Kondisi Stunting Pada Balita

dalam daftar kuesioner tersebut adalah yang dikonsumsi dalam frekuensi yang cukup sering oleh responden. (FK UNS, 2018; Nadia, 2019)

\section{METODE \\ Sampel Penelitian}

Penelitian ini dilakukan dibeberapa daerah dibawah wikayah kerja Puskesmas Pall Merah Jambi yang melibatkan 206 balita berusia $24-59$ Bulan, balita yang menajdi sampel penelitian telah melewati kriteria eksklusi seperti : Riwayat Berat Badan Lahir < 2500 gr dan Lahir prematur < 37 minggu, Balita dengan kelainan bawaan dan penyakit serius, Balita cacat pada bagian Ekstremitas, Balita dengan berat badan overweight berdasarkan perhitungan BMI, Orang tua/ Wali balita menolak ikut serta.

\section{Pengumpulan Data}

Data sekunder berdasarkan hasil laporan / profil Kesehatan Provinsi Jambi serta laporan bulanan Puskesmas Pall Merah. Data karakteristik responden diperoleh melalui wawancara menggunakan kuesioner. Data berat badan, tinggi badan dan lingkar lengan, pengukuran lingkar kepala, lingkar dada, lingkar pinggang, lingkar pinggul, lingkar lengan, tebal lemak tubuh dilakukan langsung oleh peneliti dan enumerator. Pengukuran kecukupan gizi dilakukan oleh petugas pembantu survey, pengukuran ini menggunakan metode kuesioner Food Frequency yang akan disi oleh orang tua Balita. Pengukuran Antropometri menggunakan Berat balita diukur menggunakan timbangan Tipe Bathroom scale dengan maksimum berat $100 \mathrm{~kg}$ dengan ketelitian 100 gr, Tinggi Badan Diukur menggunakan Microtoise (Vertical Measures) dengan ketelitian 0,1 cm. Lingkar Kepala diukur menggunakan Metline non elastis, Ketebalan Lemak diukur menggunakan bodyfat calipper dibagian betis dengan cara lipatan kulit diambil dengan arah vertikal pada lingkaran betis yang paling lebar pada bagian betis.

\section{Analisa Data}

Setelah didapatkan hasil pengukuran masing masing dimensi pengukuran antropometri maka dilakukan penyeragaman data, keseragaman data ini dilakukan berdasarkan tiap jenis kelamin dan usia Balita dengan tingkat kepercayaan $95 \%$. Selain itu dilakukan Uji signifikan parameter digunakan untuk mengetahui apakah sebuah peubah bebas berkontribusi nyata terhadap model. Terdapat Uji Analisis Multivariat. Untuk mengetahui hubungan antara variabel menggunakan Uji regresi Non Parametrik Spline yang memiliki fleksibilitas yang tinggi. Langkah-langkah Analisis (Stefanus, 2011):

1. Membuat pendekatan fungsi $f$ dengan model spline:

$$
f(x)=\beta_{0}+\beta_{1} x+\beta_{2} x^{2}+\beta_{3} x^{3}+\cdots+\beta_{m} x^{m}+\sum_{j=1}^{k} \beta_{j+m-1}\left(x-\lambda_{j}\right)_{+}^{m-1}
$$

2. Menerapkan model spline untuk estimasi pola hubungan Ukuran Antropometri, Ketebalan lemak dan Kecukupan Gizi.

3. Membuat scatter plot antara Ukuran Antropometri (x) - Kecukupan Gizi (y) dan Ketebalan Lemak (x) dan Kecukupan Gizi (y) untuk mengetahui hubungan antara kedua variabel.

4. Menetukan titik knots dan orde knots yang menghasilkan nilai GCV terkecil untuk setiap variabel

5. Memilih model spline terbaik dari nilai GCV yang paling minimum.

6. Melakukan pengujian normalitas.

7. Menghitung nilai koefisien Korelasi dan Nilai Residual

\section{HASIL DAN PEMBAHASAN}

Karakteristik balita sebagai responden dalam penelitian ini mencakup usia balita yang terbagi menjadi usia $\leq 36$ Bulan dan $>36$ Bulan dan Jenis Kelamin Laki - laki dan Perempuan.

Tabel karakteristik responden menunjukkan jumlah responden sebanyak 206 orang balita dengan usia balita $>36$ Bulan lebih dominan yaitu 184 orang $(89,33 \%)$, dan Jumlah Balita dengan Jenis Kelamin Perempuan sebanyak 117 orang $(56,8 \%)$.

Tabel 1. Karakteristik Responden (Balita Usia $24-60$ Bulan)

\begin{tabular}{lccc}
\hline Karakteristik & $\mathbf{n}$ & $\mathbf{\%}$ & Rerata \pm SD \\
\hline $\begin{array}{l}\text { Usia Balita } \\
\text { (Bulan) }\end{array}$ & & & $29,52 \pm 5,21$ \\
$\leq 36$ & 22 & 10,67 & \\
$>36$ & 184 & 89,33 & \\
Total & 206 & 100,0 & \\
& & & \\
Jenis Kelamin & & & \\
Laki - laki & 89 & 43,20 & $1,40 \pm 6,64$ \\
Perempuan & 117 & 56,8 & \\
Total & 206 & 100,0 & \\
\hline
\end{tabular}

\section{Deskriptif Data}

Data Ukuran Antropometri, Ketebalan Lemak, Kecukupan Gizi Balita di Wilayah Kerja Pall Merah II disajikan dalam gambar sebagai berikut :

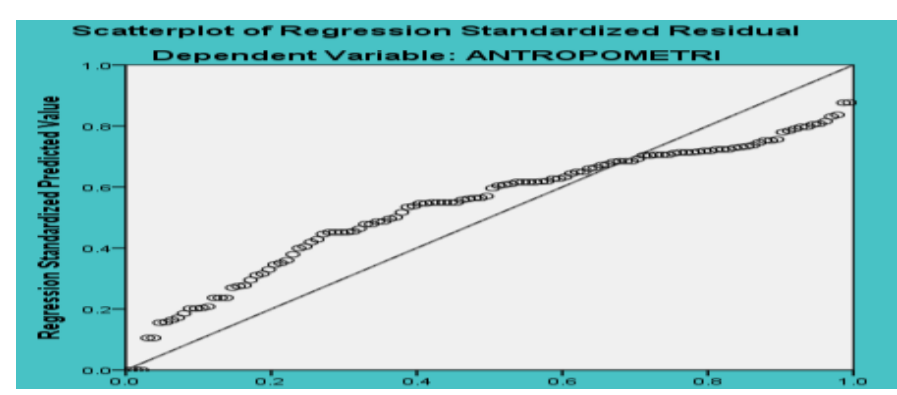

Gambar 1. Scatterplot Pengukuran Antropometri Balita 
Diane Marlin dan Rini Mustika Sarikurnia Pratama, Rancangan Grafik Ukuran Antropometri, Ketebalan Lemak Dan Kecukupun Gizi Berdasarkan Metode Regresi Spline Sebagai Prediktor Kondisi Stunting Pada Balita

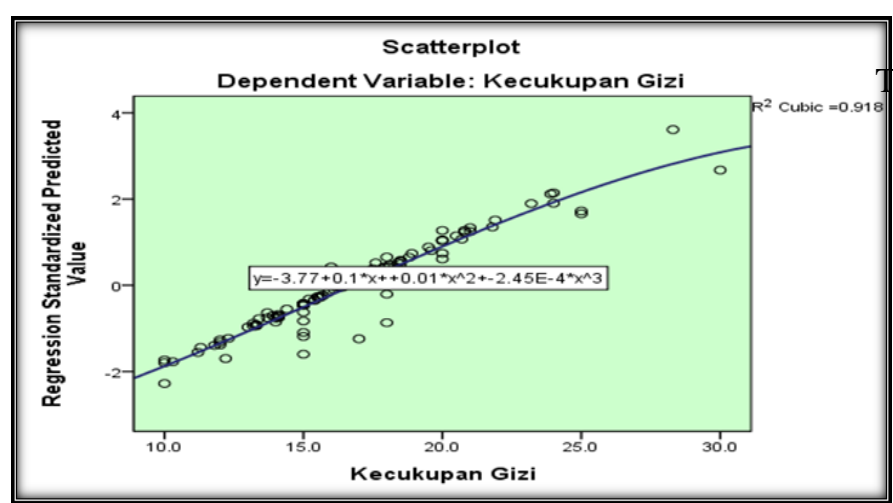

Gambar 2. Scatterplot Pengukuran Kecukupan Gizi Balita

Berdasarkan Gambar diatas terlihat bahwa kecukupan gizi balita pada interval tertentu terhadap ukuran Antropometri dengan nilai $\mathrm{R}$ cubic sebesar, 0,918. Pola pertumbuhan balita saat lahir sampai umur 15 bulan meningkat pesat, namun setelah umur 25 bulan hingga seterusnya meningkat secara bertahap, kemudian setelah umur dua tahun pertumbuhannya mulai cepat. Oleh sebab itu, digunakan model spline polinomial truncated untuk memodelkan pola hubungan antara usia dan berat badan balita yaitu:

$$
f(x)=\beta_{0}+\beta_{1} x+\beta_{2} x^{2}+\beta_{3} x^{3}+\cdots+\beta_{m} x^{m}+\sum_{j=1}^{k} \beta_{j+m-1}\left(x-\lambda_{j}\right)_{+}^{m-1}
$$

Nilai $m$ menunjukan orde spline dan $k$ menunjukan banyaknya titik knot. Knot yang optimal berkaitan dengan nilai GCV yang terkecil.

\section{Model Regresi Splain}

Berdasarkan kurva Ukuran Antropometri dan kecukupan gizi balita di wilayah Pall Merah Kota Jambi, maka untuk mendapatkan model spline yang baik dipilih dari nilai GCV yang minimum, yang dilakukan dengan cara coba-coba mulai dari bentuk spline linier maupun spline kubik, dengan satu, dua dan tiga titik knot. abel 2. Model Spline Linier, Kombinasi Ordo Linear dan Kubik dengan Titik Knot Dan Nilai GCV

\begin{tabular}{llll}
$\begin{array}{l}\text { Orde } \\
\text { Spline }\end{array}$ & Titik knot 1 & Titik knot 2 & Titik knot 3 \\
\hline Spline & K1 $=8$ & K2 $=26$ & K3 $=19$ \\
Linier & GCV $=3,897$ & GCV $=4,421$ & GCV $=4,5027$ \\
\hline Spline & K1 $=9$ & K1 $=21$ & K1 12 \\
Kubik & GCV $=2,1267$ & GCV $=3,697$ & GCV $=3,9797$ \\
\hline
\end{tabular}

Berdasarkan Tabel 1, terlihat bahwa model spline yang sesuai untuk satu titik knot adalah spline kubik karena memiliki nilai GCV terendah yaitu 2,1267 , Sehingga secara keseluruhan model spline yang sesuai untuk data pertumbuhan balita di Pall Merah adalah model spline kubik orde tiga dengan kombinasi dua titik knot yaitu knot 9 dan 21 serta nilai GCV minimum sebesar 2,1267. Dengan menggunakan software RStudio estimasi parameter untuk model spline kubik.

Berikut adalah model spline yang diperoleh adalah sebagai berikut :

$f(x)=4,0034+3,0944 x-0,01848 x^{2}+00,0983 x^{3}+$ $0,42987(x-9)^{3}-0,19933(x-21)^{3}$

Untuk mengetahui apakah sebuah peubah bebas berkontribusi nyata terhadap model. Dengan menggunakan software SPSS dilakukan Analisis multivariat bagian hasil analisis regresi linear sederhana, metode backward maka diperoleh :

Tabel 3. Estimasi Parameter Untuk Spline Kubik

\begin{tabular}{cc}
\hline Parameter & Estimasi \\
\hline$\beta_{0}$ & 4,0034 \\
$\beta_{1}$ & 3,0944 \\
$\beta_{2}$ & 0,0983 \\
$\beta_{3}$ & 0,00236 \\
\hline
\end{tabular}

Tabel 4. Analisis Multivariat Pengukuran Antropometri, Ketebalan Lemak dan Kecukupan Gizi

\begin{tabular}{clllll}
\hline Model & & Standar Error & Koofisisen Korelasi & t & P value \\
\hline Pengukuran antropometri & Tinggi Badan & 0,02 & 0,226 & 0,021 & 0,021 \\
& Berat Badan & 4,987 & 0,0478 & 0,015 & 0,046 \\
& Lingkar Kepala & 3,07 & 0,032 & 0,0049 & 0,023 \\
& Lingkar Lengan Atas & 0,127 & 0,334 & 0,000 & $<0,001$ \\
& Lingkar dada & 0,987 & 0,542 & 0,005 & 0,035 \\
Ketebalan Lemak & Lingkar Betis & 0,435 & 0,514 & 0,005 & 0,875 \\
Kecukupan Gizi & Bisep & 0,678 & 0,0074 & 0,023 & 0,576 \\
\hline
\end{tabular}

$\mathrm{R}^{2}=82,54 \%$

\section{Pembahasan}

Landasan rancangan grafik pertumbuhan Antropometri, ketebalan lemak dan kecukupan gizi balita ini mengacu ke grafik pertumbuhan bayi dan balita normal yang telah dibuat pada awal tahun 1990-an oleh WHO, grafik WHO tersebut menekankan kesamaan berbagai etnis. Grafik pertumbuhan ini didasarkan pada 6 literatur review mengenai pertumbuhan anak yang dimulai sejak lahir hingga usia 24 bulan, dan 24 bulan lebih hingga 60 Bulan. 125 negara telah mengadopsi 
Diane Marlin dan Rini Mustika Sarikurnia Pratama, Rancangan Grafik Ukuran Antropometri, Ketebalan Lemak Dan Kecukupun Gizi Berdasarkan Metode Regresi Spline Sebagai Prediktor Kondisi Stunting Pada Balita

standar pertumbuhan WHO (De Onis M, 2019) dengan mengukur tinggi badan, berat badan, dan Indeks Masa Tubuh bervariasi di antara berbagai negara bahkan di antara kelompok etnis yang berbeda di negara yang sama.

Berbeda halnya dengan Indonesia perbedaan pola asupan nutrisi membuat Indonesia belum dapat menerapkan standar Internasional tersebut. Berdasarkan hasil pengukuran dan survey di negara bagian Eropa ataupun negara modern dapat melampaui standar pertumbuhan dan referensi WHO lebih tinggi hingga satu standar deviasi, sedangkan populasi dari negara berkembang dapat memiliki hingga 2 deviasi standar di bawah ini (NCD-RisC, 2016). Di negara dengan populasi tinggi, standar WHO mengarah ke kesalahan klasifikasi dan kesalahan diagnosis, secara klinis bentuk perawakan tubuh menjadi lebih kurus dan pendek (Saari A, 2013; Christesen et al, 2016).

Beberapa alasan tidak ditemukan hubungan tersebut diduga disebabkan oleh beberapa faktor. Kejadian stunting merupakan peristiwa yang terjadi dalam periode waktu lama, sehingga tingkat kecukupan gizi menjadi hal yang penting untuk ditinjau lebih jauh. Kecukupan gizi dilihat dari sumber utama komponen makanan, lemak dan protein. Asupan protein bukan merupakan satu-satunya faktor yang memengaruhi kejadian stunting. Faktor-faktor lain yang menyebabkan anak menjadi stunting selain kurangnya asupan protein juga disertai defisiensi zat gizi mikro dalam makanan pokok yang dikonsumsi sehari - hari dan penggunaan air bersih (Lee J, 2010)

Berdasarkan hasil Uji Regresi Linear variabel pada tabel 4, yang paling menunjukan hubungan yang bermakna antara antara lingkar lengan atas dan kecukupan gizi dengan nilai $p<0,01$. Lingkaran lengan (LILA) atas mencerminkan tumbuh kembang jaringan lemak dan otot yang tidak terpengaruh banyak oleh keadaan cairan tubuh dibandingkan dengan berat badan. LILA dapat dipakai untuk menilai keadaan gizi/ tumbuh kembang pada kelompok umur prasekolah. Laju tumbuh lambat, dari $11 \mathrm{~cm}$ pada saat lahir menjadi $16 \mathrm{~cm}$ pada umur 1 tahun. Selanjutnya tidak banyak berubah pada selama 1-3 tahun.

Kebutuhan untuk grafik pertumbuhan antropometri disetiap daerah berbeda. kurva pertumbuhan standar akan menggambarkan pertumbuhan anak umur 0-59 bulan di lingkungan yang diyakini dapat mendukung pertumbuhan optimal anak. Adanya hasil penelitian ini memberi rujukan akan pentingnya mengevaluasi ulang standar ukuran atropometri yg digunakan berdasarkan karakteristik individu dan sumber utama jenis makanan yang dikonsumsi setiap daerah tidaklah sama. Belum ditemukanya ada teori atau penemuan yang mempelajari secara eksplorasi yang menyatakan penyebab anak anak atau balita dari daerah terpencil tumbuh secara berbeda. Perbedaan pertumbuhan mungkin disebabkan oleh keadaan sosial-lingkungan tertentu, perbedaan genetik juga mungkin berperan.

\section{SIMPULAN}

1. Data Ukuran Antropometri, Ketebalan lemak dan Kecukupan Gizi Balita di Puskesmas Pall Merah Kota Jambi dapat dimodelkan dengan menggunakan regresi nonparametrik spline dengan model matematis :

$$
\begin{aligned}
& f(x)=4,0034+3,0944 x-0,01848 x^{2}+00,0983 x^{3}+ \\
& 0,42987(x-9)^{3}-0,19933(x-21)^{3}
\end{aligned}
$$

2. Model spline kubik orde tiga dengan kombinasi dua titik knot yaitu knot 9 dan 21 serta nilai GCV minimum sebesar 2,1267.

3. Asumsi linear terpenuhi dengan nilai $R^{2}=82,54$. yaitu linearitas, normalitas dan residu nol konstan terpenuhi.

\section{DAFTAR PUSTAKA}

Achadi LA .2012. Seribu Hari Pertama Kehidupan Anak. Disampaikan pada Seminar Sehari dalam Rangka Hari Gizi Nasional ke 60. FKM UI, Maret 2012 Depok.

Aman B Pulungan., et al. "Indonesian National Synthetic Growth Charts". Acta Scientific Paediatrics 1.1 (2018): 20-34

Black RE, Victora CG, Walker SP, Bhutta ZA, Christian $\mathrm{P}$, de Onis $\mathrm{M}$ et al. Maternal and child undernutrition and overweight in low-income and middle-income countries. Lancet. 2013; doi:10.1016/S0140-6736(13)60937-x

Buku Manual Keterampilan Klinik Topik Antropometri. 2018. Kementerian Riset, Teknologi, Dan Pendidikan Tinggi Universitas Sebelas Maret Fakultas Kedokteran

Christesen HT., et al. "Short stature: comparison of WHO and national growth standards/references for height". PLoS One 11.6 (2016): e0157277.

De Onis M., et al. "Worldwide implementation of the WHO Child Growth Standards". Public Health Nutrition 15.9 (2012): 1603-1610.

Dhong TE., et al. "The growth of children of pre-school age in Batavia". Indian Journal of Pediatrics (1939): 163-185. Dalam Aman B Pulungan., et al. "Indonesian National Synthetic Growth Charts". Acta Scientific Paediatrics 1.1 (2018): 20-34

Dian Yosefanny, Hazmira Yozza, Izzati Rahmi H.G. 2011 "Model Spline Kuadratik Untuk Merancang Kurva Pertumbuhan Balita Di Kota Padang". Jurnal Matematika Unand Vol. Vii No. 1 Hal. 33 \{ 42 Issn : $2303\{291 x$

Gorter FJ and JH de Haas. "Gewicht en Lengte van 30 000 Schoolkinderen te Batavia". Maandschrift voor Kindergeneeskunde 15 (1947): 154-202. 
Diane Marlin dan Rini Mustika Sarikurnia Pratama, Rancangan Grafik Ukuran Antropometri, Ketebalan Lemak Dan Kecukupun Gizi Berdasarkan Metode Regresi Spline Sebagai Prediktor Kondisi Stunting Pada Balita

Dalam Aman B Pulungan., et al. "Indonesian National Synthetic Growth Charts". Acta Scientific Paediatrics 1.1 (2018): 20-34

IDAI (Ikatan Dokter Anak Indonesia).2011. Kurva Pertumbuhan WHO. Diakses 30 Juli 2019 http://www.idai.or.id/professionalresources/growth-chart/kurva-pertumbuhan-who

International Food Policy Research Institute. Global nutrition report 2014: actions and accountability to accelerate the world's progress on nutrition. 2014. Washington DC: International Food Policy Research Institute.

Kementerian Kesehatan RI. Riset Kesehatan Dasar, 2013

Lee J, Houser RF, Must A, de Fulladolsa PP, \& Bermudez OI. 2010. Disentangling nutritional factors and household characteristics related to child stunting and maternal overweight in Guatemala. Economics and Human Biology, 8(2), $188-19$

Liem Tjay Tie S and de Haas JH. "Weight and height of native and Chinese infants at Batavia". Indian Journal of Pediatrics 5.4 (1938): 219-240. Dalam Aman B Pulungan., et al. "Indonesian National Synthetic Growth Charts". Acta Scientific Paediatrics 1.1 (2018): 20-34

Millennium Challenge Account www.mcaindonesia.go.id. Diakses 25 Juli 2019

Nadia Farhani dan Viera Nu'riza Pratiwi. 2019. Pengembangan dan Pengujian Validitas Food Frequency Questionnaire untuk Menganalisis Asupan Zat Gizi Makro dan Zat Gizi Mikro pada Balita di Kecamatan Wonocolo Kota Surabaya: Pilot Project, Universitas Nahdlatul Ulama Surabaya.

NCD Risk Factor Collaboration (NCD-RisC). "A century of trends in adult human height". Elife 5 (2016): e13410.

Saari A., et al. "Multiethnic WHO growth charts may not be optimal in the screening of disorders affecting height: Turner syndrome as a model". JAMA Pediatrics 167.2 (2013): 194- 195.

Stefanus Notan Tupen 1, I Nyoman Budiantara 2. "Uji Hipotesis Dalam Regresi Nonparametrik Spline “. Prosiding Seminar Nasional Statistika Universitas Diponegoro 2011 ISBN: 978-979-097-142-4

Torlesse, H., Cronin, A. A., Sebayang, S. K., \& Nandy, R. (2016). Determinants of stunting in Indonesian children: evidence from a cross-sectional survey indicate a prominent role for the water, sanitation and hygiene sector in stunting reduction. BMC Public Health, 16(1). doi:10.1186/s12889-0163339-8

Widardo, Budiyanti, Nanang Wiyono Et Al. Buku Manual Keterampilan Klinik Topik Antropometri. 2018. Kementerian Riset, Teknologi, Dan Pendidikan Tinggi Universitas Sebelas Maret Fakultas Kedokteran
World Health Organization. 2014. WHO global nutrition targets 2025: stunting policy brief (Geneva: World Health Organization) 10

Zilda Oktarina1 dan Trini Sudiarti1 Faktor Risiko Stunting Pada Balita (24-59 Bulan) Di Sumatera (Risk Factors of Stunting among Children [2459 months] in Sumatera). 2013. ISSN 1978 - 1059 Jurnal Gizi dan Pangan, , 8(3): 175-180 